\title{
ANTIFUNGAL COMPOUND PRODUCED BY THE CASSAVA ENDOPHYTE Bacillus pumilus MAIIIM4A
}

\author{
Flávia Mandolesi Pereira de Melo ${ }^{1,2 *}$; Marli Fátima Fiore ${ }^{1}$; Luiz Alberto Beraldo de Moraes ${ }^{3}$; \\ Maria Estela Silva-Stenico ${ }^{1}$; Shirlei Scramin²; Manoel de Araújo Teixeira²,4; Itamar Soares \\ de Melo $^{2}$ \\ ${ }^{1}$ USP/CENA - Lab. de Biologia Celular e Molecular, Av. Centenário, 303, C.P. 96 - 13400-970 - Piracicaba, SP \\ - Brasil. \\ ${ }^{2}$ Embrapa Meio Ambiente - Lab. de Microbiologia Ambiental, Rod. SP 340, km 127,5, C.P. 69 - 13820-000 - \\ Jaguariúna, SP - Brasil. \\ ${ }^{3}$ USP/FFCLRP - Depto. de Química, Av. Bandeirantes, 3900 - 14040-901 - Ribeirão Preto, SP - Brasil. \\ ${ }^{4}$ UNIVÁS/MG - Lab. de Microbiologia, Av. Prefeito Tuany Toledo, 470 - 37550-000 - Pouso Alegre, MG - Brasil. \\ *Corresponding author <flamelo@cnpma.embrapa.br>
}

\begin{abstract}
In the search for new organisms and new secondary metabolites, a study was conducted to evaluate the diversity of endophytic bacteria from ethnovarieties of cassava cultivated by Brazilian Amazon Indian tribes and also to study the secondary metabolites produced by a Bacillus pumilus strain. Sixty seven cassava endophytic bacteria were subjected to 16S rRNA sequencing and FAME analysis. The bacterial profile revealed that $25 \%$ of all endophytic isolates belonged to the genus Bacillus. The isolate B. pumilus MAIIIM4a showed a strong inhibitory activity against the fungi Rhizoctonia solani, Pythium aphanidermatum and Sclerotium rolfsii. Secondary metabolites of this strain were extracted using hexane, dichloromethane and ethyl acetate. Extracts were subjected to bioautography and LC/MS analysis, which allowed the identification of pumilacidin, an antifungal compound produced by B. pumilus MAIIIM4a. The bacterial endophytic localization was confirmed by cassava cell tissue examination using scanning electron microscopy.
\end{abstract}

Key words: ESI-MS/MS, pumilacidin, endophytic bacteria, bioautography

\section{COMPOSTO ANTIFÚNGICO PRODUZIDO PELO ENDÓFITO DE MANDIOCA Bacillus pumilus MAIIIM4A}

\begin{abstract}
RESUMO: Na busca de novos organismos e novos metabólitos secundários, um estudo foi conduzido visando avaliar a diversidade de bactérias endofíticas de etnovariedades de mandioca cultivadas por tribos indígenas da Amazônia brasileira e também para estudar metabólitos secundários produzidos por Bacillus pumilus. Sessenta e sete bactérias endofíticas de mandioca foram identificadas através do seqüenciamento do gene 16S rRNA e por meio da análise de ácidos graxos (FAME). Essas análises revelaram que $25 \%$ de todos os endofíticos pertenciam ao gênero Bacillus. O isolado Bacillus pumilus MAIIIM4a apresentou forte ação inibitória contra os fitopatógenos Rhizoctonia solani, Pythium aphanidermatum e Sclerotium rolfsii. Os metabólitos secundários deste isolado foram extraídos do sobrenadante usando-se hexano, diclorometano e acetato de etila. Esses extratos foram utilizados nas análises de bioautografia e LC-MS, as quais permitiram a identificação do composto pumilacidina, um antifúngico produzido por B. pumilus MAIIIM4a. A localização das bactérias endofíticas foi confirmada examinando-se o tecido celular da mandioca através de microscopia eletrônica.

Palavras-chave: ESI-MS/MS, pumilacidina, bactéria endofítica, bioautografia
\end{abstract}

\section{INTRODUCTION}

Endophytes are microorganisms (bacterial and fungal) that inhabit a wide variety of plant tissue types without causing any apparent harm to the host (Hallmann et al., 1997). In order to colonize the plant and compete with other microorganisms, they produce many enzymes and toxins (Lima et al., 2005). Also, a variety of secondary metabolites, including enzymes, antibiotics (Pleban et al., 1997), anticancer (Stierle et al., 1993), anti-inflammatory (Trischman et al., 1994), antifungal (Korzybski et al., 1978), and biological control agents (Hallmann et al., 1997) have been isolated from endophytic microorganisms. To date, many promising endophytic bacteria have been reported as biocontrol candidates against plant pathogens. Most of them produce enzymes and antibiotics as the main action mechanisms. However, their frequent occurrence 
in agricultural crops and subsequent relevance to crop production systems is yet to be explored widely (Loeffler et al., 1986; Krebs et al., 1998). Cassava (Manihot esculenta Crantz ssp. esculenta) is one of the main species cultivated by farmers of tropical areas and it is thought to be originated from Brazilian Amazon basin, whereas many ethnovarieties have been cultivated by Indian tribes.

The cassava roots are the major carbohydrate source throughout the humid tropics for over 500 million people (FAO, 2000). Despite its global importance as a subsistence crop, cassava has not received major attention in crop research programs. In this context, studies about cassava endophytic bacteria may bring important contribution to the knowledge of the crop disease control mechanisms and the beneficial relationships between plants and bacterial endophytes communities (Teixeira et al., 2007). The aim of the present study was to provide a survey of bacterial endophytic population in cassava plants from an Indian tribe plantation of Brazilian Amazon, characterize the isolated strains and identify the antifungal metabolites produced by the isolates.

\section{MATERIALAND METHODS}

\section{Isolation and identification of endophytic bacteria}

Six healthy cassava plants were collected from different Indian tribes plantation located in the Autazes region (03 ${ }^{\circ} 18$ '003" S - 60³7'15,5" W), Amazonas State, Brazil. Freshly collected plants were placed in plastic bag, maintained in low temperature $\left( \pm 10^{\circ} \mathrm{C}\right)$ and transported to the laboratory where they were separated into stems, root and leaf and cut into sections about $1 \mathrm{~cm}^{2}$. A vigorous rinsing with sterilized distilled water and neutral detergent was used to remove adhering microorganisms. All the material (10 roots pieces, 20 stem pieces and 15 leaves pieces) were then surface disinfected using $70 \%$ ethanol for $1 \mathrm{~min}$, $2 \%$ sodium hypochlorite for 6 min, again $70 \%$ ethanol for $30 \mathrm{~s}$ to remove sodium hypochlorite and finally rinsed with sterilized distilled water (Araújo et al., 2001). To confirm the surface disinfection process the tissue segments of the final rinse were plated out onto tryptic soy agar (TSA) (Difco Laboratories, Detroit, MI, USA). Seven segments of each cassava tissue were inoculated in Petri dish containing TSA medium supplemented with $1 \mu \mathrm{L} \mathrm{mL} \mathrm{m}^{-1}$ of the fungicide benomyl, to inhibit fungal growth. The Petri dishes (replicated three times) were incubated at $27^{\circ} \mathrm{C}$ for $10 \mathrm{~d}$. After this period, endophytic bacterial colonies were transferred to plates containing fresh TSA. Individual colonies without contaminants were kept in mineral oil at $4^{\circ} \mathrm{C}$.

\section{Identification of bacteria by fatty acid methyl es- ter (FAME) analysis}

Pure bacterial cultures were grown on TSA medium for $2 \mathrm{~d}$ at $28^{\circ} \mathrm{C}$. Triplicate of $40 \mathrm{ng}$ wet mass of cells were harvested and placed into reaction tubes. One milliliter of methanolic sodium hydroxide solution (15\% $\mathrm{NaOH}[\mathrm{m} / \mathrm{v}]$ in $50 \%$ methanol $[\mathrm{v} / \mathrm{v}])$ was added to the cells and the mixture was heated $\left(100^{\circ} \mathrm{C}\right)$ in water bath for $30 \mathrm{~min}$ to saponify the cells. The fatty acids were methylated in $2.0 \mathrm{~mL}$ methanolic hydrochlorid acid solution (6N HCL in $46 \%$ methanol [v/v]) in a water bath at $80^{\circ} \mathrm{C}$ for $10 \mathrm{~min}$. The FAMEs were extracted from aqueous phase with $1.25 \mathrm{~mL}$ of methyl-tert-butyl ether: hexane $(1: 1, v / v)$. The FAME extracts were analyzed on gas chromatography (Hewlett Packard, Rolling Meadows, IL, USA). The FAME compounds were identified using the microbial identification software (Sherlock aerobe method and TSA library version 4.0) developed by MIDI Inc. (Newark, NJ, USA).

\section{Identification of bacteria by sequencing the $16 \mathrm{~S}$ rRNA gene fragment}

Pure cultures of bacteria were cultivated in $10 \mathrm{~mL}$ of TSA liquid medium and incubated for $48 \mathrm{~h}$ at $28^{\circ} \mathrm{C}$ at $120 \mathrm{rpm}$. Aliquots of $1.5 \mathrm{~mL}$ of culture were rinsed twice with $500 \mu \mathrm{L}$ of TE buffer (10 mM Tris-HCl, 1 mM EDTA pH 8.0). The cell pellets were resuspended in $500 \mu \mathrm{L}$ of TE buffer plus $30 \mu \mathrm{L}$ of $10 \%$ sodium dodecyl sulfate $[\mathrm{m} / \mathrm{v}]$ and $0.5 \mathrm{~g}$ of 0.1 -mm-diameter glass beads (BioSpect Products, Inc., Bartlesville, OK, USA). Each sample was shaken vigorously for 3 sec in a mini-bead beater (BioSpect Products, Inc). One milliliter of phenol was added; the solution was mixed well, and centrifuged at $12,000 \times g$ for $10 \mathrm{~min}$. The aqueous phase containing the DNA was extracted once with $1 \mathrm{~mL}$ of phenol-chloroform-isoamyl alcohol (25:24:1) and once with chloroform-isoamyl alcohol (24:1). The DNA was precipitated with a 0.6 volume of isopropanol and a 0.1 volume of $5 \mathrm{M} \mathrm{NaCl}$ and washed with $70 \%$ ethanol. The pellet was washed with $70 \%$ ethanol, air dried and resuspended in 50 $\mu \mathrm{L}$ sterilized ultrapure water containing RNAse (10 $\left.\mathrm{mg} \mathrm{mL}^{-1}\right)$. The DNA from each sample was finally analyzed by agarose gel electrophoresis to estimate the yield.

The 16S rRNA partial sequence was amplified from the B. pumilus MAIIIM4a genomic DNA using the primers F968 (5'-AACGCGAAGAACCTT AC-3') (Nübel et al., 1996) and R1387 (5'CGGTGTGTACAAGGCCCGGGAACG-3') (Heuer et al., 1997). Amplification was performed in a Gene Amp PCR System 2400 (Applied Biosystems, Foster City, CA, USA) using $50 \mu \mathrm{L}$ PCR mixture containing $10 \mathrm{ng}$ of genomic DNA, $0.2 \mu \mathrm{M}$ of each oligonucle- 
otide primer, $200 \mu \mathrm{M}$ dNTPs, $3.75 \mathrm{mM} \mathrm{MgCl}, 1 \times$ PCR buffer and $5.0 \mathrm{U}$ of Taq DNA polymerase (Invitrogen, Carlsbad, CA, USA). Thermal cycling was performed using a touchdown series as described by Araújo et al. (2002). PCR amplifications were then analyzed by electrophoresis using $1 \%$ agarose gel stained with ethidium bromide. Gel was viewed on an Alpha DigiDoc System Gel Documentation System (Alpha Innotech, San Leandro, CA, USA) and recorded.

The PCR fragments were purified using the Ultra Clean PCR clean-up kit (MO BIO Laboratories, Inc., Solana Beach, CA, USA) according to the manufacturer's instruction. Direct PCR sequencing reaction was performed using the purified PCR product, R1387 primer and BigDye Terminator Cycle Sequencing Ready Reaction Kit (Applied Biosystems, Foster City, CA, USA). After the completion of the sequencing reaction, a $100 \%$ isopropanol wash followed by a $70 \%$ ethanol wash was performed to remove residual dye terminators. The purified reaction was then resuspended in HiDi formamide (Applied Biosystems) and the samples were placed in an ABI PRISM 310 Genetic Analyzer (Applied Biosystems).

The nucleotide fragment sequences of 16S rRNA obtained in this study were compared with sequence information available in the National Center for Biotechnology Information database using BLAST (www.ncbi.nlm.nih.gov/BLAST). Phylogenetic tree was constructed by multiple pair-wise alignments using the CLUSTAL W computer program, version 1.8 (Thompson et al., 1994). The neighbour-joining tree (Saitou \& Nei, 1987) was built with BioEdit version 5.0.6 (Hall, 2001). The tree reliability was evaluated by bootstrap analysis with 1,000 replicates. The nucleotide sequence determined in this study has been deposited in GeneBank under accession number DQ011675.

\section{Scanning electron microscopy of endophytic bac- teria in cassava tissues}

Microorganisms-free axenic seedlings of cassava were obtained by tissue culture procedures. Three flasks containing $400 \mathrm{~mL}$ of Murashige \& Skoog medium (Murashige \& Skoog, 1962) and three with sterilized distilled water were prepared. Cassava seedlings were transferred to the flasks and $10^{8} \mathrm{CFU} \mathrm{mL} \mathrm{m}^{-1}$ of $B$. pumilus MAIIIM4a was inoculated. Non-inoculated media containing cassava seedlings was routinely used as control. After $5 \mathrm{~d}$ the cassava plants were separated into stems, roots and leaves and each tissue was cut into sections of approximately $2 \mathrm{~cm}^{2}$. Each cassava tissue section was fixed in a modified Karnovksy solution (Kitajima \& Leite, 1999) and the samples were kept at $8^{\circ} \mathrm{C}$ overnight. The samples were washed 3 times with cacodylate buffer $(0.05 \mathrm{M})$ for $10 \mathrm{~min}$ and immersed in $1 \% \mathrm{OsO}_{4}$ (in $0.05 \mathrm{M}$ cacodylate buffer, $\mathrm{pH}$ 7.2) for $1 \mathrm{~h}$. The fragments were washed five times, 15 min changes in distilled water. Samples were dehydrated in an ethanol series (30, 50, 70, 90 and $100 \%)$ for 15 min per change. The latter phase was repeated three times. Ultimately, the cassava material were critically point dried, gold sputter coated with gold and examined using a field emission scanning electron microscope (SEM) (LEO Co-operation Zeiss/Leica, Oberkochem, Germany). All experiments were performed in triplicate.

\section{Screening of bacteria for antagonism}

All bacterial isolates were screened for their activity against the pathogenic fungi Pythium aphanidermatum, Rhizoctonia solani and Sclerotium rolfsii. A plug of the fungus was placed on one side of the potato dextrose agar (PDA) plate, and a loop of bacteria was streaked down the opposite side of the plate. Control plates consisted of the fungus placed on PDA plates alone. Plates were incubated at $28^{\circ} \mathrm{C}$ for $48 \mathrm{~h}$. Antifungal activity from each bacterial isolate was recorded as the size of the zone of inhibition.

\section{Extraction of secondary metabolites}

According to the antifungal screening, one bacterium Bacillus pumilus MAIIIM4a that showed strong antifungal activity was chosen for further studies, including the characterization of its metabolites. Thus this strain was cultivated in liquid PD (potato-dextrose) medium and incubated in a shaker $(150 \mathrm{rpm})$ at $28^{\circ} \mathrm{C}$ for $72 \mathrm{~h}$. At the end of this period, the cultures were centrifuged at $10,000 \times g$ for $5 \mathrm{~min}$. and $500 \mathrm{~mL}$ of the supernatant were used for successive extractions with hexane $(200 \mathrm{~mL})$, dichloromethane $(200 \mathrm{~mL})$ and ethyl acetate $(200 \mathrm{~mL})$. The respective organic phases were collected and dried with anhydrous sodium sulfate and evaporated and then the crude extracts were obtained: $7 \mathrm{mg}$ from hexane extraction, $8 \mathrm{mg}$ from dichloromethane extraction and $8 \mathrm{mg}$ from ethyl acetate extraction.

\section{Antimicrobial activity}

The test-fungi described previously were grown in PDA medium at $25^{\circ} \mathrm{C}$ for $24 \mathrm{~h}$ and then $20 \mu \mathrm{L}$ of the hexane, dichloromethane and ethyl acetate extracts were applied in sterile disks of 7.0-mm-diameter (Sensibiodisc, Cecon, São Paulo, SP, Brazil), previously inserted in Petri dishes inoculated with fungal strains. The controls consisted of $20 \mu \mathrm{L}$ of solvent or the medium extracted in the same solvent. Zones of inhibition were recorded after two days. This experiment was performed in triplicate. 
Thin layer chromatography and bioautography

Silica gel G60 $\mathrm{F}_{254}$ alumina backed plates $(10 \times 10$ $\mathrm{cm}$ ) were used for separation and identification of inhibitory fractions. Aliquots $(10 \mu \mathrm{L})$ of each extract obtained as described above were applied and the layers developed with dichloromethane/ethyl acetate (9:1). The UV active absorbing spots were visualized at 254 and $366 \mathrm{~nm}$. For bioautography experiments, chromatograms were placed in $9 \times 9 \mathrm{~cm}$ sterile Petri dishes with covers. Overlay media (PDA, $20 \mathrm{~mL}$ ) containing a suspension of $10^{6} \mathrm{~mL}^{-1}$ cells of the fungal tests was sprayed over the developed TLC plates. After solidification of the media, the TLC plates were incubated at $25^{\circ} \mathrm{C}$. The fungal growth was observed daily and the formation of inhibition zones was recorded.

\section{GC-MS}

Extracts were derivatized with diazomethane and subjected to gas chromatography-mass spectrometry (GC-MS) analysis. GC-MS analysis was performed on a Shimadzu equipped with a $30 \mathrm{~m} \times 0.25 \mathrm{~mm} \times 0.25$ $\mu \mathrm{m}$ capillary column. The following oven program was applied: the temperature was $40^{\circ} \mathrm{C}$ programmed up to $280^{\circ} \mathrm{C}$ at $8^{\circ} \mathrm{C} / \mathrm{min}$. The carrier gas He (research grade $99.95 \%$ purity) was used at a flow rate of $1 \mathrm{~mL}$ $\mathrm{min}^{-1}$. A sample volume of $1 \mu \mathrm{L}\left(10 \mathrm{mg} \mathrm{mL}^{-1}\right)$ was injected. The injector and the transfer lines were maintained at $240^{\circ} \mathrm{C}$. The Mass Selective Detector (QP5000 ) was operated in the Electron Ionization mode at $70 \mathrm{eV}$ in the full scan range of $\mathrm{m} / \mathrm{z} 100$ to 2000 . Nist 12 and Wiley library were used to identify metabolites in the extracts.

\section{Mass spectrometry}

MS was performed using a hybrid quadrupole time-of-flight (TOF) high resolution (7.000) and high accuracy (5 ppm) Q-TOF mass spectrometer (Micromass, Manchester, UK) equipped with an electrospray ion source (ESI). The working conditions for positive and negative ESI were as follows: desolvation gas (nitrogen) was heated at $250^{\circ} \mathrm{C}$; capillary was held at a potential of $3.2 \mathrm{kV}$, and the cone voltage was set at $25 \mathrm{kV}$. MS/MS tandem mass spectra were acquired by mass-selecting the target ion using the quadrupole mass analyzer followed by $25 \mathrm{eV}$, collision induced dissociation using argon in the quadrupole collision cell and mass analysis by TOF. The crude extracts were dissolved in a mixture of methanol and water 2:1 (v/ v) and $10 \mathrm{mM}$ ammonium acetate for analysis in both positive and negative ion mode. The sample was introduced into the source at $10 \mu \mathrm{L} \mathrm{min}{ }^{-1}$ with a syringe pump.

\section{RESULTS}

Isolation and identification of endophytic bacteria

Sixty-seven strains of endophytic bacteria were isolated from six cassava plants. The taxonomic results revealed that out of 67 isolates subjected to 16S rRNA gene and FAME profile analysis, only 44 showed similarities comparing the two techniques. It was possible to identify 19 genera of endophytic bacteria in cassava plants (Table 1). More than $25 \%$ of the isolates were classified as Bacillus species. The bacteria identified in cassava were isolated from all colonizing parts of the plant. The percentage of colonization in roots was $41 \%$ of the total isolated bacteria, followed by the stem with $34 \%$ and leaves with $25 \%$. Some of the strains were present in all tissues of the plant, while others colonized specific parts. The resulting profiles were identified with microbial identification software (MIDI) using the TSBA database, version 4.0 (MIDI, Newark, Del.) and a dendrogram can be visualized in Figure 1 (Teixeira, 2004). The $16 \mathrm{~S}$ rRNA sequence of the $B$. pumilus MAIIIM4a compared favourably (98\% identity) with several sequences of B. pumilus (AF526907, AY289549, AY496869, AY167886) from public database by BLAST analysis. Phylogenetic relationships were investigated with other bacteria from Genebank using the joining method (Figure 2). All the B. pumilus strains formed a monophyletic cluster in the tree. The bootstrap analysis based on 1,000 resamplings of the neighbour-joining data, used to test the robustness and stability of the branching, showed that the B. pumilus strains sequences clustered with high bootstrap value (98\%) separated from the other species of Bacillus.

Scanning electron microscopy of cassava tissues Scanning electron microscopy analysis demonstrated that $B$. pumilus MAIIIM4a beneficially infected

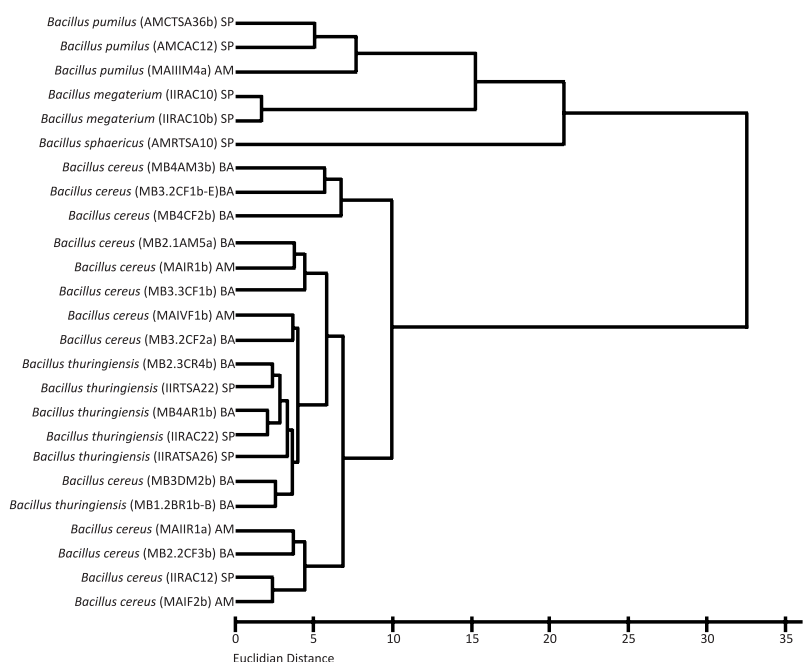

Figure 1 - Dendrogram obtained by FAME profile analysis of Bacillus strains (Teixeira, 2004). 
Table 1 - Identification of endophytic bacteria using FAME and 16S rRNA gene. The fat acids profiles were obtained comparing the data from the TSBA4.0 library (reference strains). Isolates with similarity index (SI) of 0.6 or higher were considered positively identified.

\begin{tabular}{|c|c|c|c|c|}
\hline Strain & Plant tissue & Identification & MIDIa (SI) & 16S rRNA (\% identity) \\
\hline MAIIR2b & Root & Kluyvera cryocrescens & 0.699 & 99 \\
\hline MAIVR1b & Root & Bacillus cereus & 0.782 & 99 \\
\hline MAIVR2a & Root & Streptomyces olivaceus & 0.606 & 96 \\
\hline MAIIIR1b & Root & Bacillus thuringiensis & 0.855 & 100 \\
\hline MAIIIR3b & Root & Stenotrophomonas maltophilia & 0.565 & 99 \\
\hline MAIR1b & Root & Bacillus cereus & 0.789 & 99 \\
\hline MAIIR1a & Root & Bacillus cereus & 0.854 & 98 \\
\hline MAIVR3b & Root & Burkholderia cepacia & 0.785 & 99 \\
\hline MAIIIR4a & Root & Enterobacter aerogenes & 0.791 & 99 \\
\hline MAIR2f & Root & Burkholderia cepacia & 0.754 & 90 \\
\hline MAIIIR4a-B & Root & Klebsiella penumoniae & 0.762 & 99 \\
\hline MAIR2b & Root & Bacillus cereus & 0.756 & 100 \\
\hline MAIIIR4b & Root & Acidovorax avenae & 0.584 & 99 \\
\hline MAIIIR2a & Root & Stenotrophomonas maltophilia & 0.621 & 96 \\
\hline MAIIIR2b & Root & Burkholderia cepacia & 0.733 & 94 \\
\hline MAIR2a & Root & Bacillus cereus & 0.650 & 100 \\
\hline MAIIIR3a & Root & Bradyrhizobium japonicum & 0.721 & 99 \\
\hline MAIVR2b & Root & Microbacterium hominis & 0.628 & 98 \\
\hline MAIIIM2b & Stem & Bacillus anthracis & 0.689 & 100 \\
\hline MAIM1b & Stem & Brachybacterium paraconglomeratum & 0.601 & 99 \\
\hline MAIIIM2a & Stem & Enterobacter aerogenes & 0.621 & 100 \\
\hline MAIVM3a & Stem & Bacillus anthracis & 0.632 & 99 \\
\hline MAIIIM1a & Stem & Salmonella enteritidis & 0.800 & 99 \\
\hline MAIM3a & Stem & Brevibacillus brevi & 0.600 & 99 \\
\hline MAIVM2a & Stem & Enterobacter cancerogenus & 0.751 & 100 \\
\hline MAIIM2b & Stem & Salmonella bongori & 0.802 & 97 \\
\hline$*$ MAIIIM4a & Stem & Bacillus pumilus & 0.938 & 100 \\
\hline MAIVM2b & Stem & Salmonella choleraesius & 0.931 & 100 \\
\hline MAIM1b & Stem & Escherichia coli & 0.871 & 99 \\
\hline MAIIM3a-B & Stem & Salmonella bongori & 0.623 & 96 \\
\hline MAIIIM1b-A & Stem & Serratia rubidae & 0.654 & 97 \\
\hline MAIIIM1b & Stem & Escherichia coli & 0.878 & 98 \\
\hline MAIM1a & Stem & Escherichia coli & 0.539 & 99 \\
\hline MAIF2b & Leave & Bacillus cereus & 0.806 & 100 \\
\hline MAIIIF1a & Leave & Stenotrophomonas maltophilia & 0.654 & 99 \\
\hline MAIF6b & Leave & Clavibacter michiganensis & 0.848 & 99 \\
\hline MAIIIF2b & Leave & Curtobacterium luteum & 0.659 & 100 \\
\hline MAIF1b & Leave & Bacillus pumilus & 0.748 & 100 \\
\hline MAIF1a & Leave & Microbacterium aerborescens & 0.610 & 99 \\
\hline MAIVR1f & Leave & Pseudomonas rhodesiae & 0.784 & 98 \\
\hline MAIIIR1f & Leave & Enterobacter cloacae & 0.655 & 99 \\
\hline MAIIF1a & Leave & Microbacterium imperiale & 0.784 & 99 \\
\hline MAIF4b & Leave & Ochrobactrum antropi & 0.890 & 98 \\
\hline MAIIF2a & Leave & Microbacterium imperiale & 0.747 & 94 \\
\hline
\end{tabular}

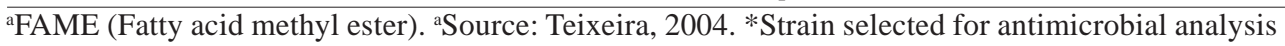


the tissues, established and colonized leaves, stems and roots of cassava plants. However, the distribution of this species was variable according to the colonization microhabitats. Populations of B. pumilus MAIIIM4a in the stem and root of cassava are shown in Figure 3. The majority of cells of $B$. pumilus MAIIIM4a invaded and colonized intracellular and intercellular sites

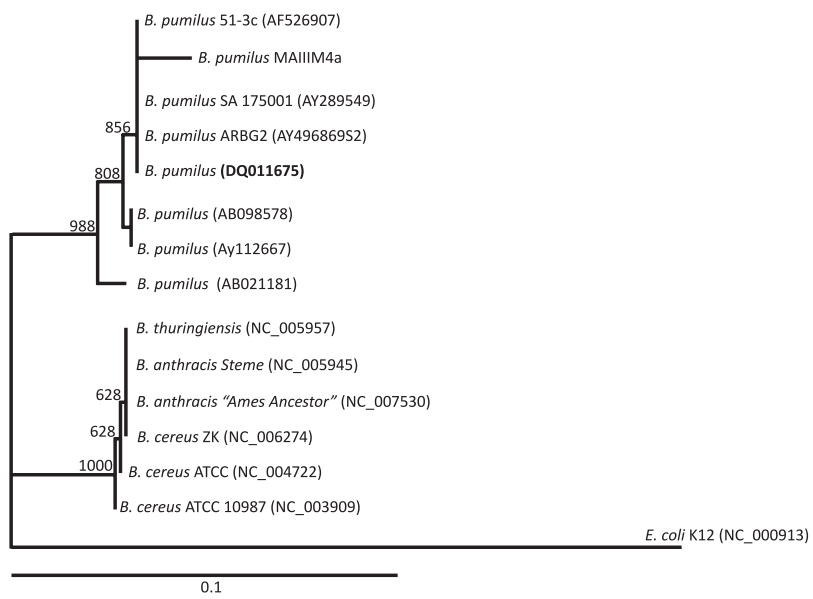

Figure 2 - A phylogenetic tree of the B. pumilus MAIIIM4a 16S rRNA gene sequence. The $16 \mathrm{~S}$ rRNA gene sequence from Escherichia coli strain K12 was treated as the outgroup. Numbers at the nodes represent percentage bootstrap values of 1000 resamplings. Sequence shown in bold was generated during this study. The scale is the expected number of substitutions per position. Nucleotide sequence obtained in this study has been deposited in GeneBank under accession number DQ011675. of cassava tissues. It was not detected presence of any bacteria in tissues of the axenic plants.

\section{Screening of bacteria for antagonism against $\boldsymbol{P}$. aphanidermatum}

A total of 67 bacterial isolates were screened for their antagonistic ability to suppress the mycelial growth of $P$. aphanidermatum in an in vitro assay. Ten isolates showed strong antagonistic activity against the phytopathogen. These antagonists were isolated from all parts of the plants, that is, $30 \%$ from roots, $20 \%$ from leaves and $50 \%$ from stem. The percentage of inhibition against $P$. aphanidermatum found is presented as follow: Enterobacter cancerogenus MAIVM2a (33\%), Bacillus anthracis MAIVM3a (26\%), B. anthracis MAIIIM2b (48\%), Kluyvera cryocrescens MAIIR2b (29\%), Bradyrhizobium japonicum MAIIIR3a (35\%), B. pumilus MAIIIM4a (54\%), B. cereus MAIF4b (33\%), Clavibacter michiganensis isidiosum MAIF6b (34\%), B. cereus MAIVM1b (51\%), Burkholderia cepacia MAIVR3b (35\%). Due to the highest antifungal activity of $B$. pumilus MAIIIM4a, this strain was chosen for further analysis.

\section{Antimicrobial activity}

Dichloromethane and ethyl acetate extracts showed high bioactivity against the phytopathogens $R$. solani, $P$. aphanidermatum and $S$. rolfsii, while the hexane extract presented low bioactivity only against $P$. aphanidermatum (Table 2).

Table 2 - Bioactivity of different B. pumilus extracts against phytopathogenic fungi.

\begin{tabular}{lccc}
\hline Extracts & $R$. solani & $P$. aphanidermatum & $S$. rolfsii \\
\hline Hexane & - & + & - \\
Dichloromethane & +++ & ++ & ++ \\
Ethyl acetate & +++ & ++ & ++ \\
\hline
\end{tabular}

( - ) Inactive (+ ) Active (++ or +++$)$ Highly active.
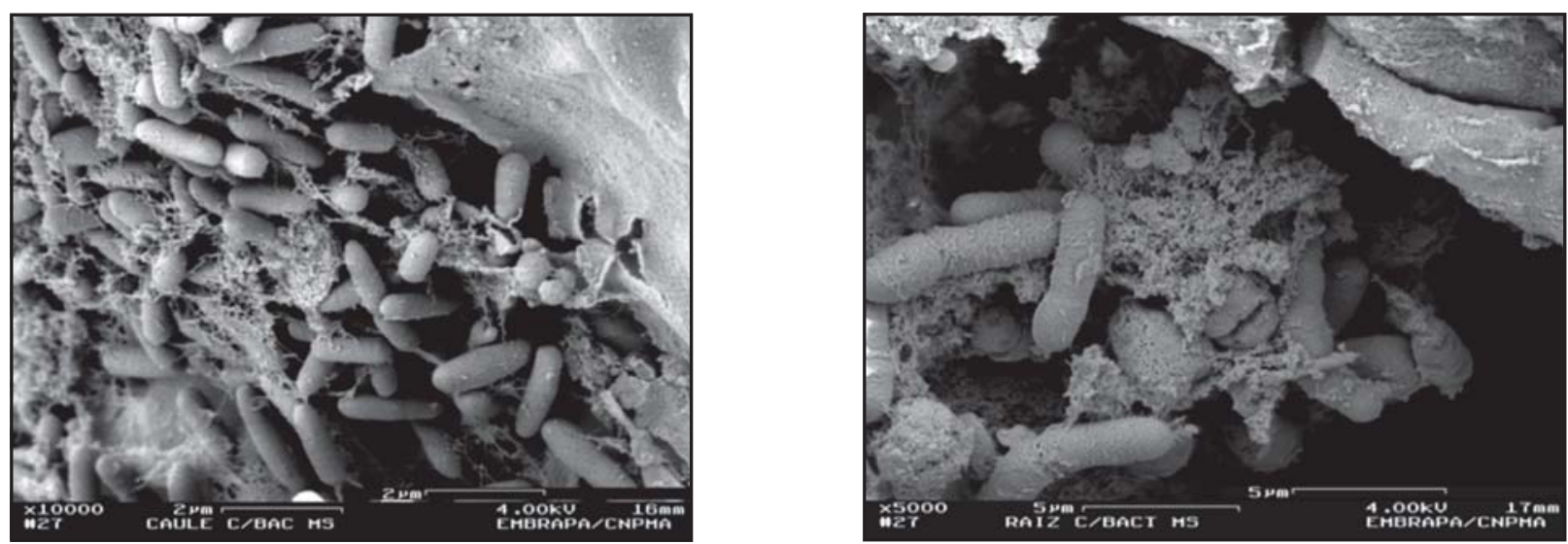

Figure 3 - Scanning electron micrographs of B. pumilus MAIIIM4a colonizing cassava tissues. a) Stem colonization; b) Root colonization. 


\section{TLC and bioautography}

The choice of extraction conditions was very important, since different solvents showed different fractions of compounds. Preliminary TLC analysis of $B$. pumilus MAIIIM4a supernatant extracted into ethyl acetate indicated that 10 fractions were obtained, while hexane extraction presented only two fractions (Table $3)$. The bioautography was performed only for the ethyl acetate extract. Clear inhibition zones at $R_{f}$ of $0.62,0.56$ and 0.42 for $B$. pumilus MAIIIM4a extracts were observed against $P$. aphanidermatum, showing that the compounds responsible for the antifungal activity are strongly apolar.

\section{GC-MS}

The results obtained by GC-MS are presented in Table 4. Mass spectra data were compared with Nist 12, Nist 62 and Wiley 139 libraries. These data suggested that hexane extracts were constituted of long chain hydrocarbons. Dichloromethane extract presented phthalate derivative, composed of aromatic and different classes of oxygenated compositions (esters, alcohols, diols, ketones and others), while ethyl acetate extract had phthalate, fatty ester, long chains of unsaturated hydrocarbons and diols.

\section{Mass Spectrometry}

Mass peaks were assigned to lipopeptide species by comparison with reference data and by mass spectrometric in situ sequence analysis of selected compounds by ESI-MS/MS. These mass data correspond well to those determined by other authors indicating the presence of pumilacidin A-E series (Kalinovskaya et al., 2002; Pabel et al., 2003) (Figure 4).

The predominant ions in ESI mass spectrum in the positive ion mode were that of $\mathrm{m} / \mathrm{z} 1036.7$, 1050.7, 1064.7 and 1078.7 (Figure 5a) and the more abundant one was that of $\mathrm{m} / \mathrm{z} 1050.7$, which corresponds to the protonated pumilacidin A with a $\mathrm{C}_{12}$ lipid carbon chain and Ile7. In a similar manner, ESI mass spectrum in the negative ion mode showed the pumilacidin A-E series [M-H] (Figure 5b). Different isoforms exist for each lipopeptide, which vary in the chain length of their fatty acid components and amino acid residues in their peptide rings, respectively.

\section{DISCUSSION}

A total of 67 endophytic bacteria were isolated from cassava plants collected in the Brazilian Amazon region. The isolation methodology used probably underestimates the real bacterial population, since it has been isolated only bacteria that could grow in culture conditions. Several isolates were identified by FAME profile analysis or 16S ribosomal RNA gene sequencing. The selected isolate MAIIIM4a was confirmed to belong to $B$. pumilus species and showed similarity with B. pumilus strains AMCTSA36b and AMCAC12. Bacillus species are found as the main endophytic bacteria in several plants, including Zea mays L. (Lalande et al., 1989), Gossypium hirsutum L. (Misaghi \& Donndelinger, 1990), Beta vulgaris (Jacobs et al.,

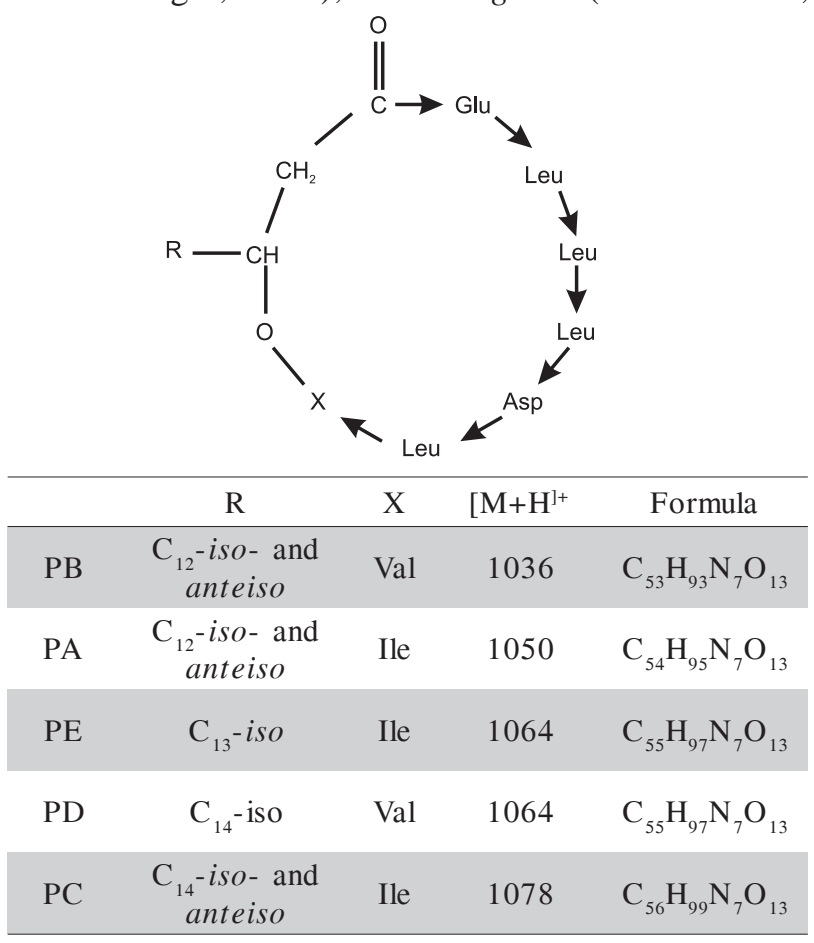

Figure 4 - Structure and mass data of lipopeptides pumilacidins. (PA-PE indicates pumilacidins series A-E).

Table 3 - $R_{\mathrm{f}}$ values for different solvent extracts using UV light to visualize spots (254 and $366 \mathrm{~nm}$ ).

\begin{tabular}{|c|c|c|c|c|c|c|c|c|c|c|}
\hline \multirow{2}{*}{ Extracts of B. pumilus } & \multicolumn{10}{|c|}{$* \mathrm{Rf}$} \\
\hline & I & II & III & IV & $\mathrm{V}$ & VI & VII & VIII & IX & $\mathrm{X}$ \\
\hline Control & 0.89 & 0.62 & 0.53 & 0.23 & - & - & - & - & - & - \\
\hline Hexane & 0.33 & 0.24 & - & - & - & - & - & - & - & - \\
\hline Dichloromethane & 0.89 & 0.80 & 0.65 & 0.60 & 0.53 & 0.23 & - & - & - & - \\
\hline Ethyl acetate & 0.89 & 0.78 & 0.71 & 0.67 & 0.62 & 0.56 & 0.49 & 0.42 & 0.29 & 0.25 \\
\hline
\end{tabular}

$* \mathrm{R}_{\mathrm{f}}$ is defined as the distance traveled by the compound divided by the distance traveled by the solvent 
Table 4 - Compounds identified in the hexane extract using GC/MS.

\begin{tabular}{|c|c|c|c|c|}
\hline Solvent & Peak number & Retention Time & Relative Abundance & Compound \\
\hline \multirow{13}{*}{ Hexane } & & $\min$. & $\%$ & \\
\hline & 1 & 3.663 & 1.16 & a \\
\hline & 2 & 4.147 & 4.51 & a \\
\hline & 3 & 4.183 & 1.85 & $n$-propil acetate \\
\hline & 4 & 5.680 & 26.79 & $\mathrm{a}$ \\
\hline & 5 & 13.556 & 2.18 & $n$-dodecane \\
\hline & 6 & 15.480 & 5.10 & $n$-tridecane \\
\hline & 7 & 17.298 & 24.15 & $n$-tetradecane \\
\hline & 8 & 18.372 & 2.96 & $\mathrm{~b}$ \\
\hline & 9 & 18.997 & 12.35 & $n$-pentadecane \\
\hline & 10 & 20.603 & 12.94 & $n$-hexadecane \\
\hline & 11 & 22.105 & 3.19 & $n$-heptadecane \\
\hline & 12 & 22.201 & 2.83 & 2,6-dimethyl octadecane \\
\hline \multirow{15}{*}{ Dichloromethane } & 1 & 3.699 & 1.11 & a \\
\hline & 2 & 4.250 & 41.64 & 3-hydroxy 2-butanone \\
\hline & 3 & 4.360 & 0.57 & $\mathrm{~b}$ \\
\hline & 4 & 5.284 & 25.64 & 2,3-butanediol \\
\hline & 5 & 5.383 & 1.03 & $\mathrm{~b}$ \\
\hline & 6 & 5.475 & 0.80 & $\mathrm{~b}$ \\
\hline & 7 & 5.602 & 5.76 & methylpropenylcarbinol \\
\hline & 8 & 5.707 & 6.50 & a \\
\hline & 9 & 5.796 & 2.13 & isopropyl acetate \\
\hline & 10 & 9.089 & 1.78 & 2,3-butanedione monooxime \\
\hline & 11 & 10.197 & 4.27 & benzyl alcohol \\
\hline & 12 & 12.065 & 1.20 & 2,6-dimethyl morfoline \\
\hline & 13 & 13.155 & 1.13 & mMethylphenylacetate \\
\hline & 14 & 20.623 & 3.36 & diethyl phthalate \\
\hline & 15 & 25.855 & 3.08 & butyl phthalate \\
\hline \multirow{15}{*}{ Ethyl acetate } & 1 & 3.824 & 0.28 & a \\
\hline & 2 & 4.263 & 1.44 & a \\
\hline & 3 & 5.547 & 46.77 & $\mathrm{~b}$ \\
\hline & 4 & 5.620 & 2.78 & 2,3-butanediol \\
\hline & 5 & 5.767 & 5.80 & a \\
\hline & 6 & 17.163 & 8.32 & 1 -pentadecene \\
\hline & 7 & 20.506 & 10.41 & 1-hexadecene \\
\hline & 8 & 23.450 & 5.64 & 1 -octodecene \\
\hline & 9 & 23.789 & 0.81 & $\mathrm{~b}$ \\
\hline & 10 & 25.238 & 0.82 & 14 methyl-pentadecanoate \\
\hline & 11 & 25.896 & 6.19 & a \\
\hline & 12 & 26.111 & 3.86 & a \\
\hline & 13 & 26.402 & 4.23 & $\mathrm{~b}$ \\
\hline & 14 & 28.546 & 1.02 & a \\
\hline & 15 & 33.053 & 1.36 & dioctyl phthalate \\
\hline
\end{tabular}

$\mathrm{a}=$ Compounds present in the culture medium. $\mathrm{b}=$ Not identified. 

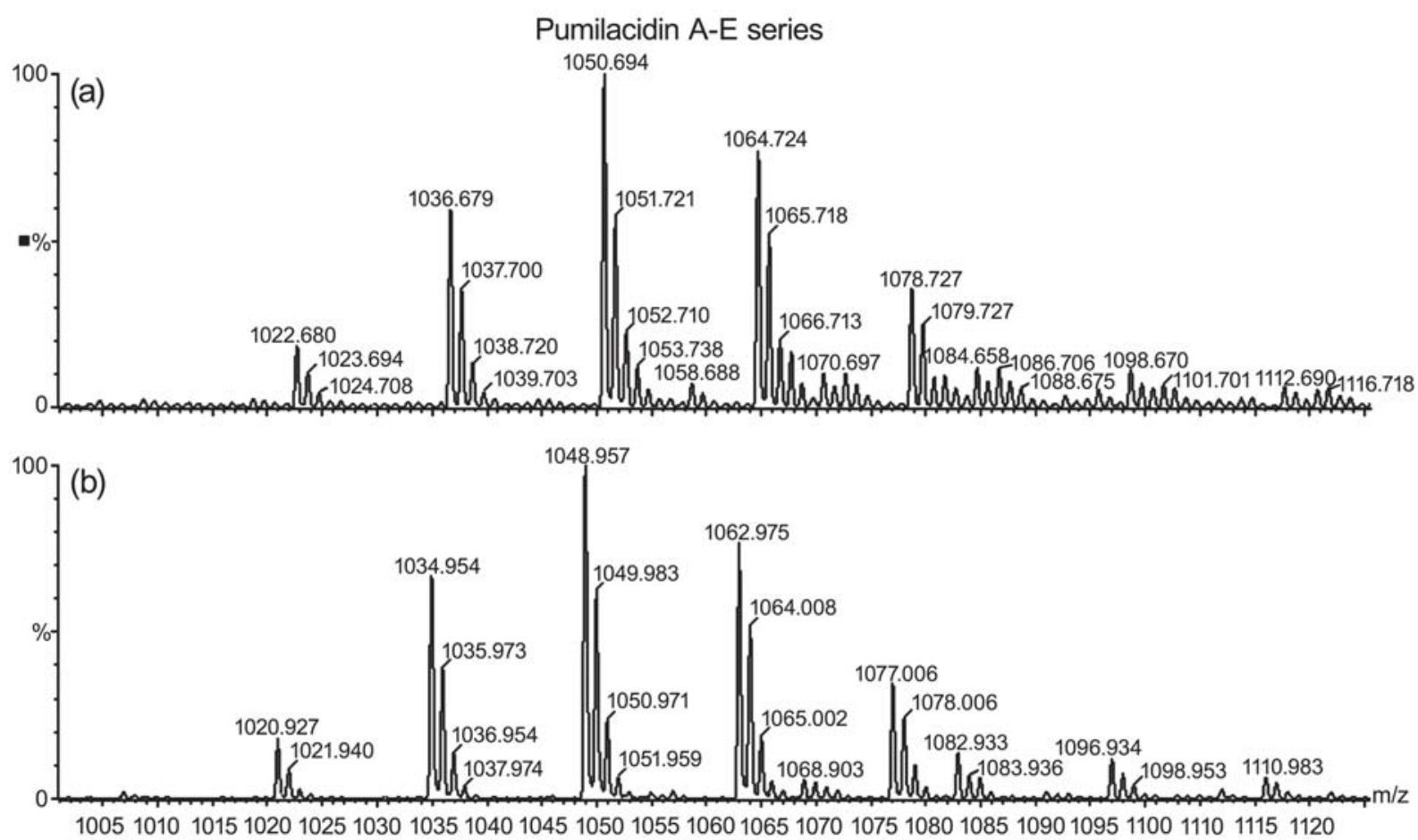

Figure 5 - ESI mass spectrum in the positive (a) and negative (b) ion mode of the pumilacidin A-E series.

1985), and Solanum tuberosum L. (Hollis, 1951), and the species that are often cited as endophytic are: $B$. cereus and B. lentus (Araújo et al., 2001), B. subtilis (Bai et al., 2002), B. megaterium (Elvira-Recuenco \& Vuurde, 2000; Araújo et al., 2001), B. insolitus and B. brevis (Sturz et al., 1997) and B. pumilus (Araújo et al., 2002). This genera has been reported as a potent biological control agent (Cook, 1986), demonstrating a great potential in agriculture.

Scanning electron microscopy was able to detect this strain in inner tissues in all parts of the plant. $B a-$ cillus pumilus MAIIIM4a colonized roots and stem, indicating that this isolate is efficient and a good candidate as biological control agent.

With the increased occurrence of phytopathogens causing plant disease, the search for new antifungal bioagent has gained urgency. The production of bioactive compounds by Bacillus species is well established (Korzybski et al., 1978; Naruse et al., 1990; Munimbazi \& Bullerman, 1998). These classes of bioactive compounds act as antifungal peptides, antifungal lipopeptides and antimicrobial polypeptides (Pabel et al., 2003). To characterize antimicrobial activity of B. pumilus MAIIIM4a, the isolate was tested against three phytopathogenic fungi: $R$. solani, $P$. aphanidermatum and $S$. rolfsii. The antifungal screening revealed that B. pumilus MAIIIM4a produced a compound with high bioactivity against $P$. aphanidermatum. The bioautography was considered an efficient test to determine antimicrobial activity, since less than $2.5 \mu \mathrm{g}$ of extract was enough to form inhibition halo around the active fractions. LC-MS/MS was able to identify a compound assigned as pumilacidin by comparison with reference data. Pumilacidin is produced by B. pumilus and are cyclic acylheptapeptide composed of a beta-hydroxy fatty acid (Naruse et al., 1990). This lipopeptide has antimicrobial (Pabel et al., 2003), antiviral and antiulcer activity (Naruse et al., 1990).

Mass spectrometric data corroborate the identification of one bioactive compound as a lipopeptide, pumilacidin, a characteristic of $B$. pumilus. This is the first time that an endophytic B. pumilus was characterized as pumilacidin producer.

\section{ACKNOWLEDGEMENT}

Financial support was provide by the Fundação de Amparo à Pesquisa do Estado de São Paulo (FAPESP 99/09177-1). F.M.P.M. was supported by a graduate scholarship from CAPES (Coordenação de Aperfeiçoamento de Pessoal de Nível Superior).

\section{REFERENCES}

ARAÚJO, W.L.; MACCHERONI JR, W.; AGUILLAR-VILDOSO, C.I.; BARROSO, P.A.V.; SARIDKIS, H.O.; AZEVEDO, J.L. Variability and interactions between endophytic bacteria and fungi isolated from leaf tissues of citrus rootstocks. Canadian Journal of Microbiology, v.47, p.229-236, 2001.

ARAÚJO, W.L.; MARCON, J.; MACCHERONI JR, W.; ELSAS, J.D.van; VUURDE, J.W.L.van; AZEVEDO, J.L. Diversity of endophytic bacterial populations and their interaction with Xylella fastidiosa in citrus plants. Applied and Environmental Microbiology, v.68, p.4906-4914, 2002. 
BAI, Y.; DÁOUST, F.; SMITH, D.L.; DRISCOLL, B.T. Isolation of plant-growth-promoting Bacillus strains from soybean root nodules. Canadian Journal of Microbiology, v.48, p.230238, 2002

COOK, R.J. Plant health and the sustainability of agriculture, with special reference to disease control by beneficial microorganisms. Biological Agriculture and Horticulture, v.3, p.211-232, 1986.

ELVIRA-RECUENCO, M.; VUURDE, J.W.L.van. Natural incidence of endophytic bacteria in pea cultivars under field conditions. Canadian Journal of Microbiology, v.46, p.1036-1041, 2000.

FAO. Championing the cause of cassava. 2000. Available in www.fao.org/NEWS/2000/000405-e.htm. Accessed 28 Sept. 2000.

HALL, T. BioEdit: version 5.0.6. Raleigh: North Carolina State University, Department of Microbiology, 2001. 192p.

HALLMANN, J.; QUADT-HALLMANN, A.; MAHAFFEE, W.F.; KLOEPPER, J.W. Bacterial endophytes in agricultural crops. Canadian Journal of Microbiology, v.43, p.895-914, 1997.

HEUER, H.; KRSEK, M.; BAKER, P.; SMALLA, K.; WELLINGTON, E.M. Analysis of actinomycete communities by specific amplification of genes encoding 16S rRNA and gelelectrophoretic separation in denaturing gradients. Applied and Environmental Microbiology, v.63, p.3233-3234, 1997.

HOLLIS, J.P. Bacteria in healthy potato tissue. Phytopathology, v.41, p.350-366, 1951

JACOBS, M.J.; BUGDEE, W.M.; GABRIELSON, D.A. Enumeration, location, and characterization of endophytic bacteria within sugar beet roots. Canadian Journal of Botany, v.63, p.12621265, 1985.

KALINOVSKAYA, N.I.; KUZNETSOVA, T.A.; IVANOVA, E.P.; ROMANENKO, L.A.; VOINOV, V.G.; HUTH, F.; LAATSCH, H. Characterization of Surfactin-like Cyclic Depsipeptides Synthesized by Bacillus pumilus from Ascidian Halocynthia aurantium. Marine Biotechnology, v.4, p.179-188, 2002.

KITAJIMA, E.W.; LEITE, B. Curso introdutório de microscopia eletrônica de varredura. 2. ed. Piracicaba: NAP/ MEPA-USP/ ESALQ, 1999. 46p.

KORZYBSKI, T.; KOWSZYK-GIFINDER, Z.; KURYTOWICZ, W. Antibiotics: origin, nature, and properties. Washington, D.C.: American Society for Microbiology, , 1978. p.501-534.

KREBS, B.; HÖDING, B.; KÜBART, S.; ALEMAYEHU-WORKIE, M.; JUNGE, H.; SCHMIEDEKNECHT, G.; GROSCH, R.; BOCHOW, H.; HEVESI, M. Use of Bacillus subtilis as biological control agent. I. Activities and characterization of Bacillus subtilis strains. Journal of Plant Diseases and Protection, v.105, p.181-197, 1998.

LALANDE, R.; BISSONNETTE, N.; COUTLEE, D.; ANTOUN, $\mathrm{H}$. Identification of rhizobacteria from maize and determination of their plant-growth promoting potential. Plant and Soil, v.115, p.7-11, 1989.

LIMA, A.O.S.; QUECINE, M.C.; FUNGARO, M.H.P.; ANDREOTE, F.D.; MACCHERONI JR, W.; ARAÚJO, W.L.; SILVA FILHO, M.C.; PIZZIRANI-KLEINER, A.A.; AZEVEDO, J.L. Molecular characterization of a $ß$-1,4-endoglucanase from an endophytic Bacillus pumilus strain. Applied Microbiology and Biotechnology, v.68, p.57-65, 2005.

LOEFFLER, W.; TSCHEN, S.-M.; VANITTANAKOM, N.; KUGLER, M.; KNORPP, E.; HSIEH, T.-F.; WU, T.-G. Antifungal effects of bacilysin and fengymycin from Bacillus subtilis F293: a comparison with activities of other Bacillus antibiotics. Journal of Phytopathology, v.115, p.204-213, 1986.
MISAGHI, I.J.; DONNDELINGER, C.R. Endophytic bacteria in symptom-free cotton plants. Phytopathology, v.80, p.808811, 1990.

MUNIMBAZI, C.; BULLERMAN, L.B. Isolation and partial characterization of antifungal metabolites of Bacillus pumilus. Journal of Applied Microbiology, v.84, p.959-968, 1998.

MURASHIGE, T.; SKOOG, F. A revised medium for rapid growth and bioassays with tobacco tissue cultures. Physiologia Plantarum, v.15, p.473-497, 1962.

NARUSE, N.; TENMYO, O.; KOBARU, S.; KAMEI, H.; MIYAKI, T.; KONISHI, M.; OKI, T. Pumilacidin, a complex of new antiviral antibiotics. Production, isolation, chemical properties, structure and biological activity. Journal of Antibiotics, v.43, p.267-280, 1990.

NÜBEL, U.; ENGELEN, B.; FELSKE, A.; SNAIDR, J.; WIESHUBER, A.; AMANN, R.I.; LUDWIG, W.; BACKHAUS, $\mathrm{H}$. Sequence heterogeneities of genes encoding $16 \mathrm{~S}$ rRNAs in Paenibacillus polymyxa detected by temperature gradient gel electrophoresis. Journal of Bacteriology, v.178, p.56365643, 1996.

PABEL, C.T.; VATER, J.; WILDE, C.; FRANKE, P.; HOFEMEISTER, J.; ADLER, B.; BRINGMANN, G.; HACKER, J.; HENTSCHEL, U. Antimicrobial activities and matrix-assisted laser desorption/ionization mass spectrometry of Bacillus isolates from the marine sponge Aplysina aerophoba. Marine Biotechnology, v.5, p.424-434, 2003.

PLEBAN, S.; CHERNIN, L.; CHET, I. Chitinolytic activity of an endophytic strain of Bacillus cereus. Letters in Applied Microbiology, v.25, p.284-288, 1997.

SAITOU, N.; NEI, N. The neighbor-joining method: a new method for reconstructing phylogenetic trees. Molecular Biology and Evolution, v.4, p.406-25, 1987.

STIERLE, A.; STROBEL, G.; STIERLE, D. Taxol and taxane production by Taxomyces andreanae, an endophytic fungus of Pacific yew. Science, v.260, p.214-216, 1993.

STURZ, A.V.; CHRISTIE, B.R.; MATHESON, B.G.; NOWAK, J. Biodiversity of endophytic bacteria which colonize red clover nodules, roots, stems and foliage and their influence on host growth. Biology and Fertility of Soils, v.25, p.13-19, 1997.

TEIXEIRA, M.A.; Diversidade de Bactérias endofíticas de mandioca (Manihotis esculenta Crantz) coletada de diferentes regiões do Brasil. São Paulo: USP/ICB, 2004. 102p. Tese (Doutorado).

TEIXEIRA, M.A.; MELO, I.S.; VIEIRA, R.F.; COSTA, F.E.C.; HARAKAVA, R. Microrganismos endofíticos de mandioca de áreas comerciais e etnovariedades em três Estados brasileiros. Pesquisa Agropecuária Brasileira, v.42, p.42-49, 2007. Available in http://www.scielo.br/pdf/pab/v42n1/06.pdf. Accessed 1 Jul. 2008.

THOMPSON, J.D.; HIGINS, D.G.; GIBSON, T.J. Clustal-W: improving the sensitivity of progressive multiple sequence alignment through sequence weighting, position-specific gap penalties and weight matrix choice. Nucleic Acids Research, v.22, p.4673-4680, 1994.

TRISCHMAN, J.A.; TAPIOLAS, D.M.; JENSEN, P.R.; DWIGHT, R.; FENICAL, W.; McKEE, T.C.; IRELAND, C.M.; STOUT, T.J.; CLARDY, J.C. Salinamide-A and salinamide-B: antiinflammatory depsipeptides from a marine streptomycete. American Chemical Society, v.116, p.757-758, 1994.

Received December 06, 2007

Accepted April 16, 2009 